\title{
Impact of burning mouth syndrome on quality of life
}

\section{Impacto da síndrome da ardência bucal na qualidade de vida}

\begin{abstract}
Objective: To determine the impact of Burning mouth syndrome (BMS) on the quality of life of patients by means of the World Health Organization Abbreviated Instrument for Quality of Life Assessment (WHOQOL-26).

Methods: A total of 116 patients were selected, 58 with BMS and 58 controls. Individuals with changes in the hemogram and in the blood levels of glucose, iron, folic acid and vitamin $\mathrm{B}_{12}$ were excluded, as well as those who used antidepressant and/or anxiolytic drugs or who showed a salivary flow rate of less than $0.1 \mathrm{~mL} / \mathrm{min}$.

Results: The overall score of the WHOQOL-26 was significantly lower in the group with the disorder $(P<0.001)$. The patients with BMS also displayed significantly lower scores when compared to controls in relation to the psychological and physical domains of the instrument $(P=0.005$ and $P<0.001$, respectively). There was no significant difference between BMS and control patients with respect to scores of the social and environment domains.

Conclusions: BMS interferes with the quality of life of patients in a negative way, and therefore, its management is a challenge for the clinicians, who should treat the individual with this disorder in a broader context.
\end{abstract}

Key words: Burning mouth syndrome; quality of life; oral health

\section{Resumo}

Objetivo: Avaliar o impacto da Síndrome da Ardência Bucal (SAB) na qualidade de vida dos pacientes por meio do Instrumento Abreviado de Avaliação de Qualidade de Vida da Organização Mundial de Saúde (WHOQOL-26).

Métodos: Foram selecionados 116 pacientes de ambos os sexos, com idade mínima de 40 anos, 58 portadores de SAB e 58 indivíduos-controle. Indivíduos com alterações no hemograma, nas concentrações de glicose, ferro, ácido fólico e vitamina B 12 foram excluídos, bem como aqueles que utilizassem fármacos antidepressivos, ansiolíticos ou que apresentassem velocidade de fluxo salivar inferior a $0,1 \mathrm{~mL} / \mathrm{min}$.

Resultados: $O$ escore geral do WHOQOL-26 foi significativamente inferior no grupo com a doença $(P<0,001)$. Os pacientes com $S A B$ também apresentaram escores significativamente inferiores em relação aos domínios psicológico e físico do instrumento $(P=0,005$ e $P<0,001$, respectivamente). Não houve diferença significativa entre os grupos quanto aos escores dos domínios social e ambiental do questionário.

Conclusão: A SAB interfere de forma negativa na qualidade de vida dos pacientes, por isso, é importante que o cirurgião-dentista avalie o paciente com a doença dentro de um contexto mais amplo.

Palavras-chave: Síndrome da ardência bucal; qualidade de vida; saúde bucal

\author{
Juliana Cassol Spanemberg ${ }^{\circ}$ \\ Anna Paula Dias a \\ Bernardo Ottoni Braga Barreiro a \\ Karen Cherubini a \\ Maria Antonia Z. de Figueiredoa \\ Fernanda Gonçalves Salum a
}

- School of Dentistry, Oral Medicine Division, São Lucas Hospital - Pontifical Catholic University of Rio Grande do Sul (PUCRS), Porto Alegre, Brazil

\author{
Correspondence: \\ Juliana Cassol Spanemberg \\ Hospital São Lucas PUCRS \\ Av. Ipiranga, 6690 - Sala $231-2^{\circ}$ andar \\ Porto Alegre, RS - Brasil \\ $90610-000$ \\ E-mail: jcs.odonto@yahoo.com.br
}

Received: March 1, 2012

Accepted: August 8, 2012

Conflict of Interests: The authors state that there are no financial and personal conflicts of interest that could have inappropriately influenced their work.

Copyright: (c) 2012 Spanemberg et al.; licensee EDIPUCRS. This is an Open Access article distributed under the terms of the Creative Commons AttributionNoncommercial-No Derivative Works 3.0 Unported License. 


\section{Introduction}

Burning mouth syndrome (BMS) is a complex disorder that is characterized, mainly by a warm or burning sensation in the oral mucosa without changes on physical examination (1-4). It affects more often patients of middle or advanced age, and women at a ratio of 7:1 relative to men (3). The episodes of burning manifest spontaneously and the sites most affect are the tongue, hard palate and lower labial mucosa $(3,5)$.

The etiology of BMS is still unknown and various hypotheses have been proposed to explain its etiopathogenic mechanism. The first studies attributed great importance to the endocrine system (6) and the tissue degenerative alterations inherent to aging. Later, investigations on the etiology of BMS turned to exploring neuropathic (7-9) and psychopathological disturbances (10). Anxiety, stress and depression are described as possible causes, since these symptoms have been found more often in patients with BMS (11). These psychological disturbances play an important role in the modulation of pain, where they are able to increase or decrease the transmission of peripheral receptors, modifying the perception of pain. They cause a reduction in pain threshold, and normal stimuli are perceived as painful (12). Besides, improvement in disorder symptoms has been observed as a result of cognitive-behavioral therapy and with the use of anxiolytic drugs $(4,13)$.

The concept of quality of life $(\mathrm{QV})$ has various meanings, and despite that there is still no consensus, it is defined as "an individual's perception of their position in life in the context of the culture and value system in which they live and in relation to their goals, expectations and standards and concerns" (14). The oral diseases have been increasingly recognized as important causes of a negative impact on daily performance and on the QV of the individuals and of society in general (15-16). The aim of the present clinical cross-sectional study was to determine the impact of burning mouth syndrome on the quality of life of patients using the World Health Organization Abbreviated Instrument for Quality of Life Assessment (WHOQOL-26).

\section{Methods}

The study was approved by the Committee of Ethics in Research of the Pontifical Catholic University of Rio Grande do Sul (PUCRS) (09/04888) in accordance with national and international guidelines and regulations of the Declaration of Helsinki. A total 116 patients were selected; 58 patients with burning mouth syndrome and 58 control individuals, matched by gender and age. The patients with BMS were selected in the Oral Medicine Division of São Lucas Hospital of PUCRS and the control patients, without the disorder, were selected from the dental clinics of this institution. All patients agreed to participate and signed an informed consent form.

The group of patients with BMS included individuals of both genders, with a minimal age of 40 years, who reported burning mouth symptoms for at least six months and who, on physical examination, showed a clinically normal mucosa (1). We excluded patients with erosive or ulcerated oral lesions, infectious oral lesions or malignant neoplasias or who had undergone chemo- or radiotherapy. Also excluded were patients with alterations in the hemogram, erythrocyte sedimentation rate, serum levels of glucose, iron, folic acid and vitamina $B_{12}$, taking antidepressant or anxiolytic drugs or hormonal replacement therapy and with a salivary flow rate less than $0.1 \mathrm{~mL} / \mathrm{min}$.

\section{Procedures}

Diagnosis of BMS was established when the patient reported symptoms of warmth, burning, pain and/or pruritus in the oral mucosa, which was otherwise normal (1-4). Quality of life was quantitatively assessed in patients, by means of the WHO Abbreviated Instrument for Quality of Life Assessment (WHOQOL-26). This instrument is selfexplanatory and consists of 26 questions, two general one on the quality of life and 24 facets. The 26 questions are divided into four domains: physical, psychological, social relations and environment (17). The questions referring to physical domain include aspects of the type of pain, discomfort, energy, fatigue, sleep, rest, activities of daily life, dependence on medication or treatments and ability to work. In the psychological domain, the questions refer to positive feelings, thinking, learning, memory, concentration, self-esteem, body image, appearance, negative feeling, spirituality, religiosity and personal beliefs. The social relations domain encompasses questions related to personal relations, social support and sexual activity. The last domain, environment, refers to questions of physical safety, home environment, financial resources, health concerns, recreation opportunities, leisure and physical environment (pollution, noise, traffic, climate) (18). When the respondent did not understand the meaning of some question, the interviewer explained it simply and slowly (assisted application). The scores of the patients were calculated utilizing the WHOQOL-26 syntax (19).

\section{Analysis of the data}

The data were initially analyzed by descriptive statistics. The scores of the WHOQOL-26 questionnaire were compared using Student's $t$ test for independent samples. Differences with $P \leq 0.05$ were considered significant. The software utilized to carry out the statistical analyses was SPSS version 18.0.

\section{Results}

In both groups, $89.7 \%(\mathrm{n}=52)$ of the 58 patients were females and $10.3 \%(n=6)$ males. The mean age of the individuals with BMS was $62.2( \pm 9.0)$ years old and of the control patients, $60.6( \pm 9.4)$ years old. The oral sites most affected by the burning symptoms were the apex, dorsum and sides of tongue, lips and palate (Table 1). The time of development of the syndrome ranged from six months to 20 years, with a median of 24 months. 
Table 1. Demographic distribution of the patients in the groups studied

\begin{tabular}{lcc}
\hline & $\begin{array}{c}\text { BMS group } \\
(\mathbf{n}=58)\end{array}$ & $\begin{array}{c}\text { Control group } \\
(\mathbf{n}=58)\end{array}$ \\
\hline Mean age \pm SD & $62.2 \pm 9.0$ & $60.6 \pm 9.4$ \\
Age range & $41-82$ & $41-85$ \\
Males & $06(10.3 \%)$ & $06(10.3 \%)$ \\
Females & $52(89.7 \%)$ & $52(89.7 \%)$ \\
Sites of burning & & \\
$\quad$ Apex of tongue & $42(72.3 \%)$ & \\
Dorsum of tongue & $37(63.7 \%)$ & \\
$\quad$ Sides of tongue & $29(50.0 \%)$ & \\
$\quad$ Lips & $15(25.8 \%)$ & \\
Palate & $18(31.0 \%)$ & \\
$\quad$ Other sites & $07(12.0 \%)$ & \\
\hline
\end{tabular}

Table 2 gives the overall score and the scores of the psychological, physical, social relations and environment domains of the WHOQOL-26 instrument. The BMS group showed an overall score significantly lower than that of the control group $(P<0.001)$. In respect to the physical and psychological domains, the BMS group also showed significantly lower scores $(P<0.001$ and $P=0.005$, respectively). There was no significant difference between the groups with respect to the social relations and environment domains of the instrument.

Table 2. Means of scores obtained with WHOQOL-26 in the patients with burning mouth syndrome (BMS) and controls

\begin{tabular}{lccc}
\hline \multirow{2}{*}{$\begin{array}{c}\text { WHOQOL-26 } \\
\text { Domains }\end{array}$} & $\begin{array}{c}\text { BMS group } \\
\mathrm{n}=58\end{array}$ & $\begin{array}{c}\text { Control group } \\
\mathrm{n}=58\end{array}$ & \multirow{2}{*}{$\boldsymbol{P}^{*}$} \\
\cline { 2 - 3 } & Mean \pm SD & Mean \pm SD & \\
\hline Physical & $61.8 \pm 18.1$ & $72.7 \pm 14.2$ & $<0.001$ \\
Psychological & $64.2 \pm 16.6$ & $72.5 \pm 14.4$ & 0.005 \\
Social relations & $67.7 \pm 18.3$ & $72.0 \pm 19.2$ & 0.219 \\
Environment & $64.1 \pm 14.8$ & $67.3 \pm 15.1$ & 0.246 \\
Overall score & $60.3 \pm 18.0$ & $79.5 \pm 14.8$ & $<0.001$ \\
\hline
\end{tabular}

* Student's t-test for independent samples, significant if $P \leq 0.05$.

\section{Discussion}

Burning mouth syndrome is a complex disorder of unknown etiology, in which psychological and neuropathic factors appear to be involved (4). The lack of a curative treatment and persistence of the symptoms for months or even years, causes suffering and can exert a negative influence in the daily routine of the affect individuals. In this study, individuals with the syndrome showed a significant lower overall score of quality of life compared to the control group. In all domains of the WHOQOL-26 questionnaire, the scores of the patients with BMS were also lower than those of the control patients. The difference between the groups was statistically significant in the physical and psychological domains of this instrument. BMS interferes with physical domain, because of persistent pain or discomfort affect patients with this disorder, interfering with their well-being. Besides, the syndrome is intimately related to emotional alterations such as anxiety, depression and stress (20-21), which explains the difference between the case and control groups observed in the psychological domain of the questionnaire.

The results obtained corroborate other cross-sectional studies which demonstrated that patients with BMS have lower quality of life scores when compared to healthy controls (22-25). Lopez-Jornet et al. (22) found that individuals with BMS showed lower scores with respect to quality of life in all domains of the Spanish version of the SF-36 questionnaire (Medical Outcome Short Form Health Survey).

Lopez-Jornet et al. (23) investigated the quality of life of 216 patients with oral mucosa diseases. The lowest scores were found in the patients with burning mouth syndrome. Ni Riordain et al. (24) observed that after treatment, patients with BMS exhibited improvement in quality of life, demonstrating that the disorder has a negative impact on physical, mental and social well-being. Souza et al. (25) described the impact of BMS on health-related quality of life in patients with this disease. SF-36 scores were significantly lower in all domains for patients with BMS and OHIP-49 scores were higher for individuals with disease.

The instruments that evaluate the quality of life are utilized to measure the effects of chronic diseases in different groups of patients and to better understand how the disease interferes with day to day activities, identifying specific strategies for the management of these individuals. The necessity to use a short instrument that demands little time to fill out, but with satisfactory psychometric characteristics, prompted us to choose the WHOQOL-26, the abbreviated version of the WHOQOL-100. The patients in this study, for the most part, did not show difficulty in responding to the questionnaire.

The mean age of the individuals with the syndrome was 62.2 years old and $89 \%$ were females. These results corroborate studies in the literature which report the predilection of this disorder for females of middle and advanced ages $(22,25-27)$. In this study, the sites most affected by symptoms of burning were the tongue (78.3\%), lips (25.8\%) and palate (31\%). Grushka et al. (27) and Evans and Drage (3) also demonstrated that BMS symptoms manifest in more than one site of the oral mucosa, where the tongue, hard palate and lower lip are most involved. Due to its chronic nature and to the psychological alterations commonly observed in patients with this syndrome, many treatments have been described with the aim of attenuating the symptoms. The use of behavioral and topical interventions $(13,21)$ such as capsaicin (28-29), alpha-lipoic acid (30-31), clonazepam (32) and others have been tested in the treatment of BMS. 
Studies on quality of life are important to understand the impact of diseases on the daily routine of patients, because in this way it is possible to treat them in a holistic way in a more efficacious manner. Based on the methods employed in this study, it can be concluded that BMS has a negative impact on physical and psychological well-being and thereby exerts a negative influence on the quality of life of the patients. The management of these patients is a challenge for the clinicians, who should treat the individual with this disorder in a broader context, offering alternatives to attenuate and minimize the symptoms of BMS.
References
1. Brailo V, Vuéiaeeviae-Boras V, Alajbeg IZ, Alajbeg I, Lukenda J, Eurkoviæe M. Oral burning symptoms and burning mouth syndrome-significance of different variables in 150 patients. Med Oral Patol Oral Cir Bucal 2006; 1 1:e252-5.

2. Danhaver SC, Miller CS, Rhodus NL, Carlson CR. Impact of criteria-based diagnosis of burning mouth syndrome on treatment outcome. J Orofac Pain 2002;16:305-11.

3. Evans RW, Drage LA. Burning mouth syndrome. Headache 2005;45:1079-81.

4. Minguez-Sanz MP, Salort-Llorca C, Silvestre-Donat FJ. Etiology of burning mouth syndrome: a review and update. Med Oral Patol Oral Cir Bucal 2011; 16:e144-8.

5. Fernandes CSD, Salum FG, Bandeira D, Pawlowski J, Luz C, Cherubini K. Salivary dehydroepiandrosterone (DHEA) levels in patients with the complaint of burning mouth: a case-control study. Oral Surg Oral Med Oral Pathol Oral Radiol Endod 2009; 108:537-43.

6. Wardrop RW, Hailes J, Burger H, Reade PC. Oral discomfort at menopause. Oral Surg Oral Med Oral Pathol 1989;67:535-40.

7. Albuquerque RJ, Leeuw R, Carlson CR, Okeson JP, Miller CS, Andersen AH. Cerebral activation during thermal stimulation of patients who have burning mouth disorder: an fMRI study. Pain 2006;122:223-34.

8. Forssell $H$, Jääskeläinen $S$, Tenovuo $O$, Hinkka S. Sensory dysfunction in burning mouth syndrome. Pain 2002;99:41-7.

9. Lauria G. Trigeminal small-fiber sensory neuropathy causes burning mouth syndrome. Pain 2005; 1 15:327-32.

10. Matsuoka H, Himachi M, Furukawa H, Kobayashi S, Shoki H, Motoya R. Cognitive profile of patients with burning mouth syndrome in the Japanese population. Odontology 2010;98:160-4.

11. Amenábar JM, Pawlowski J, Hilgert J, Hugo FN, Bandeira DR, Lülher F et al. Anxiety and salivary cortisol levels in patients with burning mouth syndrome: case-control study. Oral Surg Oral Med Oral Pathol Oral Radiol Endod 2008; 105:460-5.

12. Low PA, Dotson RM. Symptomatic treatment of painful neuropathy. JAMA 1998; 280: 1863-4.

13. Zakrzewska JM, Forssell H, Glenny AM. Interventions for the treatment of burning mouth syndrome. Cochrane Database Syst Rev. The Cochrane Library 2005:CD002779.

14. WHOQOL Group. The development of the World Health Organization quality of life assessment instrument (the WHOQOL). In: Orley J, Kuyken W, (editors). Quality of life assessment: international perspectives. Heigelberg: Springer Verlag 1994:41-60.

15. Leão AT, Cidade MC, Varela JR. Impactos da saúde periodontal na vida diária. Rev Bras Odontol 1998; 5:238-41.

16. Buczynski AK, Castro GF, Souza IP. O impacto da saúde bucal na qualidade de vida de crianças infectadas pelo HIV: revisão de literatura. Cienc Saude Colet 2008; 13: 1797-1805

17. Fleck MPA, Lousada S, Xavier M, Chachamovich E, Vieira G, Santos L et al. Aplicação da versão em português do instrumento de avaliação de qualidade de vida da Organização Mundial da Saúde (WHOQOL-100). Rev Saude Publ 1999;33:198-205.

18. Fleck MPA. The World Health Organization instrument to evaluate quality of life (WHOQOL-100): characteristics and perspectives. Cienc Saude Colet 2000; 5:33-38.

19. Pedroso B, Pilatti LA, Gutierrez GL, Picinin CT. Cálculo dos escores e estatística descritiva do WHOQOL-bref através do Microsoft Excel. Rev Bras Qualidad Vida 2010;2:31-3.

20. Gao J, Chen L, Zhou J, Peng J. A case-control study on etiological factors involved in patients with burning mouth syndrome. J Oral Pathol Med 2009;38:24-8.

21. Patton LL, Siegel MA, Benoliel R, De Laat A. Management of burning mouth syndrome: systematic review and management recommendations. Oral Surg Oral Med Oral Pathol Oral Radiol Endod 2007;103:S39.1-13.

22. López-Jornet P, Camacho-Alonso F, Lucero-Berdugo M. Quality of life in patients with burning mouth syndrome. J Oral Pathol Med 2008;377:389-94.

23. López-Jornet P, Camacho-Alonso F, Lucero-Berdugo M. Measuring the impact of oral mucosa disease on quality of life. Eur J Dermatol 2009; 19:603-6.

24. Ni-Riordain R, Moloney E, O'Sullivan K, McCreary C. Burning mouth syndrome and oral health-related quality of life: is there a change over time? Oral Dis 2010;16:643-7. 
25. Souza FTA, Santos TPM, Bernardes VF, Teixeira AL, Kümmer AM, Silva TA et al. The impact of burning mouth syndrome on health-related quality of life. Health Qual Life Outcomes. $2011 ; 29 ; 9: 57$.

26. Bergdahl M, Bergdahl J. Burning mouth syndrome: prevalence and associated factors. J Oral Pathol Med 1999;28:350-4.

27. Grushka M, Epstein JB, Gorsky M. Burning mouth syndrome. Am Fam Physician 2002;65:615-20.

28. Espinosa LS, López JP, Frutos RR. Síndrome de boca ardiente. Eficacia de la aplicación tópica de capsaicina. Estudio Piloto. Av Odontoestomatol 2004;20:297-304.

29. Silvestre FJ, Silvestre-Rangil J, Tamarit-Santafé C, Bautista D. Application of a capsaicin rinse in the treatment of burning mouth syndrome. Med Oral Patol Oral Cir Bucal $2011 ; 17: 1-4$.

30. Femiano F, Gombos F, Scully C. Burning Mouth Syndrome: open trial of psychotherapy alone, medication with alpha-lipoic acid (thioctic acid), and combination therapy. Med Oral $2004 ; 9: 8-13$.

31. Femiano F, Gombos F, Scully C. Burning mouth syndrome: the efficacy of lipoic acid on subgroups. J Eur Acad Dermatol Venereol 2004;18:676-8.

32. Grémeau-Richard C, Woda A, Navez ML, Attal N, Bouhassira D, Gagnieu MC et al. Topical clonazepam in BMS: a randomized placebo-controlled study. Pain 2004;108:51-7. 